\title{
Urbanization And Moral Corruption: The House of Mirth
}

\section{Kentleşme ve Ahlaki Çöküntü: The House of Mirth}

http://dx.doi.org/10.22559/folklor.1549

Figun Dinçer*

\begin{abstract}
Edith Wharton (1862-1937) generally deals with the social and individual problems of the upper-class of her time in most of her novels. Some of her works are known to be the novels of manners with some central themes of sexuality, materialism, and the manners of the families. One of the themes in The House of Mirth (1905), as Blake Nevius (1953: 55) notes, is the waste of human and spiritual resources which in America went hand in hand with the exploitation of the land and forests. Morality can be considered as one example of how it is reflected as a waste of human and spiritual resources. The present study is an attempt to evaluate the reflections of urbanization and the corruption in the moral values especially related with the marriage institution due to urbanization and materialism and how the characters suffer at the hands of social manacles while struggling with reputation, which also demonstrates the corruption. The problems caused by urbanization are also observed within the hostile relationships among the women, which even causes the death of Lily Bart.
\end{abstract}

Keywords: urbanization, morality, women, the House of Mirth

Öz

Edith Wharton (1862-1937), romanlarında genellikle yaşadığı dönemin üst sınıf insanlarının toplumsal ve bireysel sorunlarını ele alır. Çoğu eseri, üslup romanları olarak bilinir ve üst sınıf ailelerin üslupları, cinsellik ve maddiyatçılık gibi temaları içerir. The House of Mirth (1905) romanı, Blake Nevius'ın da dediği gibi, Amerika'da toprak ve ormanların sömürülmesiyle aynı anda insani ve ruhsal kaynakların da heder edildiğini gösterir (1953: 55). Bu eserde işlenen ahlaki çöküntü de insani ve ruhsal kaynakların nasıl heba edildiğinin bir örneği olarak görülebilir. Bu çalışmada, kentleşme ve materyalizm yüzünden ahlak değerlerinde özellikle evlilik kurumunda yaşanan yozlaşma ve kentleşme olgusu, ayrıca eserdeki karakterlerin, yozlaşmanın bir delili de olan, itibarları için mücadele ederken nasıl sosyal kelepçeler içinde acı çektikleri incelenmiştir. Kentleşmenin getirdiği sorunlar da özellikle Lily Bart’ın ölümüne neden olan kadınlar arası düşmanca ilişkiler içinde ele alınmıştır.

Anahtar sözcükler: kentleşme, ahlak, kadınlar, the House of Mirth

* Yrd. Doç. Dr., Bursa Uludağ Üniversitesi Eğitim Fakültesi Yabanci Diller Eğitimi Bölümü. figun@uludag.edu. tr, ORCID: 0000-0002-8275-816X 
Edith Wharton (1862-1937) generally deals with the social and individual problems of the upper-class of her time in her novels. Some of her works are known to be the novels of manners with some central themes of sexuality, materialism, and the manners of the families. One of the themes in The House of Mirth (1905), as Blake Nevius (1953: 55) notes, is the waste of human and spiritual resources which in America went hand in hand with the exploitation of the land and forests. Morality can be considered as one example of how it is reflected as a waste of human and spiritual resources. The House of Mirth is an excellent example of the Gilded Age, in which industrialization and thus urbanization causes the waste of morality at the beginning of the $20^{\text {th }}$ century. Marilyn McEntyre sees "moral diminishment of cities as an inevitable byproduct of urbanization" $(2008,85)$. The period is deliberately pictured by Wharton, who was a member of the New York aristocracy. She describes the lives of different people from different social levels who have been under the influence of the urbanization process. Within the same period of the urbanization process, too, a French art called "the art nouveau" was flourished. It seems to foster this situation through the upper-class people's giving great importance to façade, or the period seems to emerge due to these social issues as also revealed in the novel. This intermingled matter is visible through the jewelry, home furnishings, and clothing, which are valued for reflecting their wealth in society. Women are primarily chosen even for their beauty to marry and the wives seem to demonstrate their men's wealth. For this reason, a "good marriage" is considered to be kind of a business; women look for a wealthy man to marry and men look for a marriageable girl who is beautiful and young. The present study is an attempt to evaluate the signs of urbanization and the corruption in the moral values especially related to the marriage institution due to urbanization and materialism and how the characters suffer at the hands of social manacles while struggling with reputation, which also demonstrates the corruption. The problems caused by urbanization are also observed within the hostile relationships among the women, which even causes the death of Lily Bart.

During the industrial flourishing period, the cities in the United States grew. When the Civil War broke out, the country was a country of farms, villages, and small towns except for the northeastern seaboard. Most of its citizens were involved in agricultural pursuits and small family businesses. By the turn of the century, only about one-third of the population lived on farms. New York had grown from a city of 500,000 in 1850 to a metropolis of nearly 3,500.000 persons by 1900, many of whom are recent immigrants from central eastern and southern Europe. The vast majority of all wage earners were employed by corporations and large enterprises, 8.5 million as factory owners. Millions of people participated in the prosperity that accompanied this explosive industrial expansion, but the social costs were immense (Norton Anthology, 1985: 2).

The House of Mirth reflects the characteristics of urbanization and its social problems. As well known, urbanization is a process of moving to cities in an increased proportion. 
Mostly as a result of growing industrialization, cities offer hope for a better standard of living to people through employment opportunities. The positive and negative outcomes of urbanization can be observed throughout the novel. It brings much easiness to daily life in the city where flocks of people migrate from rural places to seek a better life or to gain bread at least. Technical innovations make life easier; railroads introduce new types of transportation. The mass-transit lines, streetcars, and trains connect the cities and people. Louis Auchingcloss' (1964) states that "there were immigrants in plenty to staff the great houses of Fifth Avenue, and the steam yacht and motorcar had removed geographical limits to pleasure-seeking" (344). In the House of Mirth, the first chapter proves this additional information as in the narrator's description of one moment: "Lily goes to the Grand Central Station where she takes the train to Bellomont among the 'rush' and the 'dull tints of the crowd' (HM: 5).

Transportation makes it possible for people to live in suburbs. The dirt and rush of the cities drew the rich to the suburbs where they could afford to live on their private worlds away from the other common people as to how the Trenors did in the novel. Their rich friends prefer enjoying out of the city and even out of the country; they spend the summers in Europe. The Trenors give a party at Bellomont that is far from the "madding crowd" of the city. One Sunday, they are taken to the church by an omnibus (HM: 55), and in the following season, they are invited to Monte Carlo, when they go by their steam-yacht, called Sabrina. As we see, urbanization and technology simultaneously increase supporting each other. Technical innovations like the yacht and that omnibus help the upper class to join the invitations for entertaining.

The Telegraph and the telephone are the inventions during the urbanization process in the United States. In the novel, it is observed that the usage of the telephone happens to be one of the characteristics of city life but among the rich people only. We understand that only the upper-class enjoy this technology: "Mrs. Trenor, a member of the rich class in New York society says; “...that you wouldn't like me to telephone for Lawrence Selden" (HM: 49). Only rich people afford to buy and use home phones.

Another outcome of urbanization is that population influx causes the urgent need for the solution of the housing problem, which is also reflected in the novel. The big cities like New York and Chicago are not ready to meet the sudden and intense problems of the newcomers who are keen on migrating increasingly day by day. So, the role of technology is strongly felt in building systems: "the balloon-frame house replaced heavy timber construction in the 1830 s and made it possible for a building to proceed more rapidly and with greater quantity than in the past. In 1848, James Bogardus introduced the use of cast-iron columns and weight-bearing walls supporting the structure of nonresidential buildings which eliminated the need for heavy masonry construction and which opened the internal space of buildings so that factories and warehouses could 
maximize their unimpeded use of floor space" (54). ${ }^{1}$ Tall building construction which is considered one of the signs of urbanization is another important factor boldly treated in Wharton's novel. Simon Rosedale's "flat-house with its marble porch and pseudoGeorgian façade," his "Benedick standing among new brick and limestone houses" is intentionally described in the book to give a picture of 1905 from the aspect of the gradually changing face of the city (HM: 8).

Rosedale's building can be considered to be an example of the economical features of urbanization in the first quarter of the 1900s; increased capital investment is observed in this period. Concerning this outcome, we see that the newly rich Rosedale invests some of his money into that building for rent as he has done well in the Stock Exchange. In addition to Rosedale's example, Mme. Regina's millinery shop is a symbol of capital investment and the changing role of women in society. Just half a century ago, only widowed women could run their dead husbands' shop. As a result of industrialization, women start to work mostly with lower wages than men. Since the early years of industrialization, women have founded their own unions. The first labor federation (WTUL) is established in 1903. Similar to these movements or settlements, Edith Wharton mentions Gerty Farish's Girls'Club. She gathers the girls in need and collects a 'liberal fraction of the amount' to use for their benefits (HM: 118). This is a kind of charity club but still, it is a good start for women's solidarity.

Since many people migrate to big cities from rural places and immigrated from different countries, the balance between the supply and demand in the labor is not equal, and thus the number of employments is less than the number of the people seeking vacant places in jobs. Therefore, people are obliged to struggle hard to get their share. Some people would be successful or lucky to be on the top levels of the stair. Simon Rosedale and the Brys in the novel are the ones who are "the new rich, the post-Civil War millionaires, 'the lords of Pittsburgh', whom Wharton dubbed the 'invaders', as the peculiarly corrupting force. Their limitless fortunes and equally limitless vulgarity seem to sweep away not only old standards of taste and decorum but old standards of morality. However, Auchincloss remarks that the 'invaded,' the forces of her old brownstone, genteel New York, made love to the invaders... Wharton saw that invaders and invaded would bury the hatchet in a noisy, stamping dance, and she saw also the pathos of the individual who was fated to be trampled under the feet of those boisterous truce makersthe pathos of her heroine, Lily Bart. She stems from both worlds." (1971, 69-70).

During this period, due to the increase in industrialization and urbanization, especially the upper class seem to rush in luxury purchases and to use their money to show their material power and as for women, they use the money to be both consumer and object of consumption. Being well aware of the material values of the society, Lily Bart explains it to Lawrence Selden:

http://ambounds.org/Class/Ch5-Ch6.pdf 
She surveyed him critically. 'Your coat's a little shabby - but who cares? It doesn't keep people from asking you to dine. If I were shabby no one would have me: a woman is asked out as much for her clothes as for herself. The clothes are the background, the frame, if you like: they don't make success, but they are a part of it. Who wants a dingy woman? We are expected to be pretty and well-dressed till we drop - and if we can't keep it up alone, we have to go into partnership.'

For this negative outcome of urbanization, Marilyn McEntyre states that "urban life itself seems to foster small-mindedness, petty ambition, aesthetic sterility, and moral myopia" (2008: 84). Her explanation highlights the general portrait of the characters in the novel, as well. They "acquire and maintain their status by displaying how much they can afford to waste" (HM: 1). Despite badly criticized by Lily's Aunt, playing card games is kind of a symbol of their wealth no matter how much they win or lose. Even by losing money, they afford to gain their status in high society. Other examples are that they spend a huge amount of money on women's dresses, parties and expensive gifts for couples in wedding ceremonies. As Marilyn McEntyre (2008) states, women are taught to trade on beauty as their one asset in a cruel marriage market, taught to desire the position and comforts money can buy, and unable to disengage themselves from the false economy in which they are implicated even when it drives them to despair. The dehumanization and isolation are also seen in using women as commodities and thus their efforts to look beautiful and marriageable all the time. Jung Hwa Oh (2003) explains that "they are purchased to be seen and demonstrative of wealth". The woman is the property of the man therefore he ornaments his property to reflect his wealth. Reflecting the influence of Art Nouveau, women are like elegant decorative art objects in curved lines that men are ready to invest in them. Lily, in her tableau vivant, stands as a living object for all women in that period. ${ }^{2}$

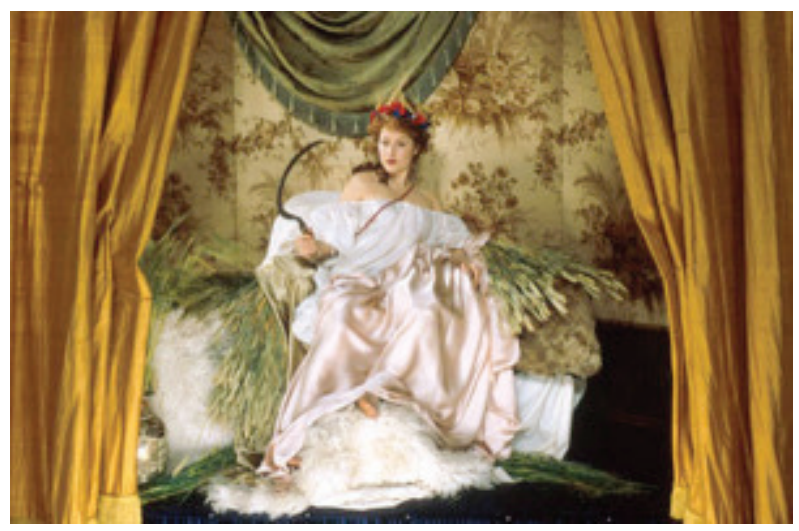

As Marilyn Jones Lyde (1959) remarks that "the post-Civil War aristocracy had placed increasing importance on appearance, assuming that honor and good manners, if not identical, were at least equivalent, and virtue was that which avoided disturbing the familiar pattern of social custom. The attitude prepared the way for the corruption and eventual disintegration of social convention in America. Manners, unlike honor, flourish

Lily Bart/Gillian Anderson poses as Watteau's "Summer" in a "tableau vivant" 
primarily among the well to do. Consequently, as more and more emphasis was placed upon mere etiquette, the lower classes, identifying the aristocracy with such superficial manifestations of wealth as decorum, came to regard money as the chief characteristic of aristocratic respectability" (108). The new rich believe that only enough amount of money is necessary to enter the aristocracy. Money is regarded as a means of getting respectability in the eyes of other people. For example, Simon Rosedale, the new rich, wants to purchase a higher status in the aristocracy, which will not accept him if he is poor even if he were born blue-blooded. He declares his money-based marriage proposal to Lily:

"I've got the money, he continued, clearing his throat, "and what I want is the woman-and I mean to have her too"... "I generally have got what I wanted in life, Miss Bart. I wanted money and I've got more than I know how to invest; and now the money doesn't seem to be of any account unless I can spend it on the right woman...I want my wife to make all the other women feel small. I'd never grudge a dollar that was spent on that. But it isn't every woman can do it, no matter how much you spend on her... What I want is a woman who'll hold her head higher the more diamonds I put on it..." (HM: 184-5).

Rosedale wants to invest his money in Lily, who will be a perfect ornamental object for displaying his wealth and to solidify his social status. However, through the end of the novel, Lily lacks financial stability and loses her respect according to the social codes of the New York aristocracy. Therefore, Rosedale does not see her as a means of investment for his purposes anymore, so he leaves Lily.

As Rosedale breaks off relations with Lily then, all her friends do the same and leave her alone. Although they have used her for their secretarial works in organizing the parties, they do not have any loyalty for her. Her beauty becomes a threat to them. Louis Auchincloss (1971) argues that her beauty is the light in which each of her different groups would like to shine, but when they find that it illuminates their ugliness, they want to put it out (72). Their ugliness, I assume, is not only a physical but also moral and emotional one as being jealous and detrimental. Lily, then, becomes a "worn-out" commodity and no longer marketable.

The life of these characters in the House of Mirth reveals a double standard of morality between men and women in the novel. When it comes to understanding moral corruption, we can turn to Gardiner's description based on Kant's ideas. Moral corruption is: a tendency to rationalize which casts doubt on the validity and/or strictness of moral claims by seeking to pervert their status and substance and in doing so aims to make those claims better suited to our wishes and inclinations, and destroys the characteristics of the virtue of which we respect them (Gardiner 2011:307). Destroyed characteristics are observed in the novel in many places. A man has an affair with a married woman or a married man has an affair with a woman as in the case of Gus Trenor and Lily Bart and Judy Trenor and her flirts, and Bertha Dorset's extramarital affairs. The striking point in Judy's case is that she flirts openly without losing respectability in the society because she is a rich, beautiful and married woman; these are the criteria enough to be respected by the upper 
class of New York City. These people also reveal that marriages and relationships with others mean something as long as financial security exists. Oh (2003) states that "Wharton criticizes the way how the marriage system of capitalist society brings about the isolation, suffering, and dehumanization on these male characters." Bertha Dorset, for instance, is secure and powerful in her husband's wealth. She is not happy with her husband, thus, she takes lovers, spends his money as she pleases. She has the power to control society and makes Lily Bart rejected by the people. She has such a great influence on people because she is married to a rich man. Bertha is only one of those dehumanized people. She is like the others who suffer from a peaceful mind and heart.

Another example of moral corruption is seen in the fact that New York high society in the early 1900 s determined their social fortune according to their social reputation through some deceitful games and tricks. For this, even blackmail is regarded as something one can have the right to do it. They manipulate everything to secure their social standing and Lily Bart was no different. She is forced to leave all her moral values to secure her standing in high society. She cannot decide to act according to her moral principles or not in blackmailing Bertha Dorset. However, she could not do it. Although the social codes of the high society blackmail are a very acceptable way to clean her defamation, she has to leave all her dreams to realize her social and material dreams within the aristocracy. The social codes and social pressure prove that the moral corruption of the high society despite providing social comfort whether degraded or not. Lily Bart, in this case, highlights their corruption although she sacrifices all her dreams and comfort and even her life eventually.

These people can be regarded as morally corrupt people since they justify evil acts in their minds to be fair. They are figuratively blind with the gilt of money, "of both new and old New York, seem strangely and vindictively united in a constant readiness to humiliate her: Grace Stepney to tell tales on her, Mrs. Peniston to disinherit her, Bertha Dorset to abandon her in a foreign port, Gus Trenor to try to seduce her, his wife to say he has. And in the end, when she finally compromises and is willing to marry Rosedale, it is too late. He will not have her, and she falls to the job at the milliner and the ultimate overdose of sleeping tablets. But we finish the book with the conviction that in the whole brawling, terrible city Lily is the one and only lady" (Auchincloss, 1971, 70).

The House of Mirth reflects the economic and social changes in the United States caused by industrialization and urbanization in the early $20^{\text {th }}$ century and draws a picture of the New York aristocracy of which moral corruption is a consequence. Corruption is observed in the social structure: in the marriage system, material values, and relationships. Being an economic necessity for women who are treated as a commodity, the marriage institution is based on materialism. To be purchased, the women of the New York aristocracy need to be purchased. So, they are obliged to look beautiful as ornaments with curved lines like the pieces of the Art Nouveau, flourished within the same period as the novel. The novel is also a kind of historical record of the industrial and urban improvements with all the technological innovations of the age from Wharton's perspective. 
In this high society of New York which Lily Bart tries hard to be a member, the rich gain their reputations through lies and deception as Wharton reflects in the novel. Although Lily is morally superior to this society, she well knows that she must use her beauty and social status to obtain social power and money like the other rich and married women. Indeed she is in kind of a dilemma between her morality and her weakness to be a member of this society. Eventually, she cannot escape to find herself in a moral opposition of the two worlds. While she is with Selden she feels comfortable and lives the moral world but on the other hand, she feels another kind of comfort with the rich in the commercialized and immoral world of Trenor, Dorset, and the others. In this world, one's public credibility is determined by his or her wealth and marriage no matter immoral he or she is. So there is no room left for Lily to survive because she has no social and financial credit anymore where Bertha is more powerful yet immoral. Instead of accepting to be a mistress of Gus Trenor whom she is deeply indebted, she tries to find a way to pay him back. This shows her underlying morality unlike the members of high society. In addition to this, Lily refuses to use the letters of Bertha Dorset who wrote to Selden. For Rosedale, she loses this opportunity. She could blackmail Bertha and earn money, but Lily again behaves according to her moral principles and heads to her sad ending and she is found to be dead in a very poor hotel room by Selden. Lily's death and before her way of surviving in the opposing worlds indicate that she acts as the victim of unscrupulous society. People like Trenors, Dorset, and Rosedale push her into a very cruel social and financial tragedy. The values within this century first make her an objet d'art, marriage commodity, and finally a victim.

\section{References}

Auchincloss, Louis (1971). Edith wharton-a woman in her time, The Viking Press.

Gardiner, Stephen, B. (2011). A perfect moral storm. The Ethical Tragedy of Climate Change, Oxford University Press.

Lyde, Marilyn Jones (1959). Edith wharton-convention and morality in the work of a novelist, University of Oklahoma Press.

McEntyre, Marilyn (2008). The House of Mirth: Isn't there a quieter place? Interdisciplinary Studies in Literature and Environment, Winter.

Nevius, Blake (1953). Edith wharton: A study of her fiction, University of California.

Norton Anthology of American Literature, Second Edition, Vol:2, Norton Company, Inc., 1985.

Oh, Joo Han (2003). The House of Mirth as the location of the performativity of gender, Journal of English and American Studies, December 2003, Vol: 2, Ewha Institute for English and American Studies.

Wharton, Edith (1964). The House of Mirth, The New American Library, Inc.

\section{Electronic Resource}

Note: This study was briefly presented in the "Uludag University, II International Philosophy Congress,

October 11-13,2012. http://ambounds.org/Class/Ch5-Ch6.pdf (Accessed: Sept. 2, 2012) 


\title{
Sindemi: Kuzey Kıbrıs, Seks İşçiliği, Pandemi
}

\section{Syndemics: North Cyprus, Sex Workers, Pandemia}

\section{Zihniye 0kray *}

\section{Öz}

Covid-19 pandemisi dünyada olduğu gibi Kuzey Kıbrıs'1 da etkilemiştir. Son 30 yılda alan yazına dâhil olan sindemi kavramı sosyal ve çevresel bileşenlerle hastalık yükünü artıran faktörler olarak değerlendirilmeye başlanmıştır. Covid-19 pandemisi sırasında özellikle kırılgan diye nitelendirilen meslek grupları ve bireyler pandemiden diğerlerine göre daha fazla ve olumsuz yönde etkilenmiştir. Dünya çapında özellikle seks işçileri ile ilgili alan yazın taraması ile birlikte seks işçilerinin sağlı hizmetlerine erişemedikleri, şiddete maruz kaldıkları ve hâlihazırda var olan damgalanma ve ayrımcılığın şiddetinin arttığı tespit edilmiştir. Kuzey Kıbrıs’ta uzun yıllardır gündemi meşgul eden gece kulüpleri ve buralarda konsomatris adı altında çalıştırılan seks işçilerinin pandemi sırasındaki durumları ilgili alan yazın açısından tartışılmıştır.

Anahtar sözcükler: Sindemi, Pandemi, Kuzey Kıbrıs, seks işçileri

\begin{abstract}
Covid-19 pandemic affected Northern Cyprus like other countries in the world.. The concept of syndemia, which has been included in the literature in the last 30 years, has started to be considered as factors that increase the disease burden with social and environmental components. During the Covid-19 pandemic, especially vulnerable occupational groups and individuals were affected by the pandemic more and more negatively than others. With the literature review on sex workers around the world, it has been determined that sex workers cannot access health services, are exposed to violence, and the current stigma and discrimination have increased. The nightclubs that have been on the agenda in Northern Cyprus for many years and the situation of sex workers who are employed under the name of consomatris during the pandemic are discussed in terms of the relevant literature.
\end{abstract}

Keywords: Syndemics, pandemic, North Cyprus, sex workers

$\bar{*}$ Doç.Dr., Lefke Avrupa Üniversitesi, Fen Edebiyat Fakültesi, Psikoloji Bölüm. ORCID ID: 0000-0002-9117-4991 